\title{
56. INTERSTITIAL WATER STUDIES, LEG 34
}

\author{
Susan Brady and Joris M. Gieskes, Scripps Institution of Oceanography, La Jolla, California
}

\begin{abstract}
Interstitial water studies on sediments recovered during Leg 34 have revealed no significant changes in the chemical composition with depth, except for dissolved silica and manganese. Although the sediments are characterized by important contributions of active ridge-derived material, basaltic components seem negligible. Postdepositional chemical reactions (if any) must occur in such a fashion that no imprint on the chemical composition of the interstitial waters occurs, or at such slow rates that any such changes in composition are annihilated by diffusional exchange processes.
\end{abstract}

\section{INTRODUCTION}

Previous studies of the chemical composition of interstitial waters of marine sediments recovered during the Deep Sea Drilling Project have often revealed large concentration gradients in calcium and magnesium ions (Manheim and Sayles, 1974; Gieskes, 1974; Sandstrom and Gieskes, 1974). Often such gradients are caused by reactions involving the alteration of basaltic and/or volcanic materials (Lawrence et al., in press; Gieskes et al., in press) in the sediment column and/or in the underlying igneous basement. As the sites drilled during Leg 34 in the Bauer Basin and on the Nazca plate were expected to have some important volcanic contributions, we decided to analyze the interstitial waters recovered from Sites 319, 320, and 321.

Previous studies in the Bauer Basin area (Bischoff and Sayles, 1972; Sayles and Bischoff, 1973; Dymond et al., 1973) showed that the surface sediments of the Bauer Basin are characterized by high iron and manganese contents and low aluminum values. This is a typical observation in so-called "metalliferous" ridge crest deposits (Boström, 1973; Piper, 1973). Previous workers found that much of the clay fraction consists of iron-rich smectite (nontronite) (Sayles and Bischoff, 1973; Dymond et al., 1973), which could be of a detrital (redeposited?) nature. Interstitial water analyses in the first few meters (Bischoff and Sayles, 1972) showed little variation from seawater composition over the first 8 meters, except for slight increases in manganese and dissolved silica concentrations.

\section{RESULTS}

The results of the compositional analyses of the interstitial waters are presented in Table 1 . Note the rather low chlorinity values at Site 321 . We believe these to be due to experimental error, particularly if one considers the constant salinity values and the constancy in other ion concentrations.

In Table 2 we present analyses of the bulk chemical composition of these sediments, carried out by $\mathrm{K}$. Boström and co-workers and kindly made available to us by Dr. Kurt Boström. The calcium values are probably high by about $10 \%$, but the other values appear to be reliable (Boström, personal communication). The bulk of sodium values probably represent sea salt or interstitial water salt contributions except, perhaps, in the upper parts of the holes.

\section{DISCUSSION}

We shall first briefly discuss observations at each site. This will then be followed by some more general remarks.

\section{Site 319}

No significant change in the interstitial waters has been observed with the exception of dissolved silica and manganese. Even the dissolved silica values are rather constant here, perhaps reflecting the reported absence of opaline skeletal debris. $\mathrm{SiO}_{2}$ contents (Table 2) are not very high (usually $<35 \% \mathrm{SiO}_{2}$ on a carbonate-free basis), but the $\mathrm{Si} / \mathrm{Al}$ ratio (atomic) is usually higher than 5 , reaching very high values in Samples 2-3, 0-10 cm and 3$3,0-10 \mathrm{~cm}(\mathrm{Si} / \mathrm{Al}=18)$. A more detailed study of the nature of the clay fraction may be warranted here to explain these high $\mathrm{Si} / \mathrm{Al}$ ratios.

\section{Site 320}

Again, this hole is characterized by the absence of any chemical concentration gradients in the interstitial fluids, except for dissolved silica and manganese. The high manganese values indicate generally prevailing reducing conditions, notwithstanding the virtual absence of a significant gradient in dissolved sulfate. The high dissolved silica values in the first 20 meters reflect the presence of opaline skeletal debris.

\section{Site 321}

Again, no significant concentration gradients have been observed, except for dissolved manganese and silica. The latter constituents typically reflect the presence of opaline silica in the upper portion of the hole.

\section{Discussion}

In all three holes the X-ray data (see Zemmels and Cook, this volume) show the presence of both zeolites, phillipsite and clinoptilolite. These materials are probably the products of alteration of volcanic matter. 
TABLE 1

Interstitial Water Composition

\begin{tabular}{|c|c|c|c|c|c|c|c|c|c|c|c|c|}
\hline $\begin{array}{c}\text { Sample } \\
\text { (Interval in } \mathrm{cm} \text { ) }\end{array}$ & $\begin{array}{l}\text { Depth } \\
\text { (m) }\end{array}$ & $\begin{array}{c}p \mathrm{H} \\
\text { (punch- } \\
\text { in) }\end{array}$ & $\begin{array}{l}p \mathrm{H} \\
\text { (comb } \\
\text { elect) }\end{array}$ & $\underset{(\mathrm{meg} / 1)}{\mathrm{Alk}}$ & $\begin{array}{c}\mathrm{Cl} \\
(\% \circ)\end{array}$ & $\begin{array}{c}S \\
(\% 0)\end{array}$ & $\begin{array}{c}\mathrm{SO}_{4} \\
(\mathrm{mmole} / 1)\end{array}$ & $\begin{array}{c}\mathrm{Ca} \\
(\mathrm{mmole} / 1)\end{array}$ & $\begin{array}{c}\mathrm{Mg} \\
\text { (mmole/1) }\end{array}$ & $\begin{array}{c}\mathrm{Sr} \\
(\mathrm{ppm})\end{array}$ & $\begin{array}{c}\mathrm{Mn} \\
(\mathrm{ppm})\end{array}$ & $\begin{array}{c}\mathrm{SiO}_{2} \\
(\mu \mathrm{mole} / 1)\end{array}$ \\
\hline \multicolumn{13}{|l|}{ Site 319} \\
\hline $\begin{array}{l}1-3,0-10 \\
1-5,0-10 \\
2-3,0-10 \\
3-3,0-10 \\
5-6,0-10 \\
7-5,144-150 \\
9-2,140-150 \\
11-2,142-150 \\
11-5,142-150 \\
12-3,0-7\end{array}$ & $\begin{array}{r}3.0 \\
6.0 \\
12.5 \\
22.0 \\
46.0 \\
64.4 \\
78.0 \\
97.9 \\
102.4 \\
107.5\end{array}$ & $\begin{array}{l}7.38 \\
7.35 \\
7.32 \\
7.35 \\
7.425 \\
7.39 \\
7.41 \\
7.39 \\
7.41 \\
7.35\end{array}$ & $\begin{array}{l}- \\
7.48 \\
7.51 \\
7.53 \\
7.52 \\
7.56 \\
7.54 \\
7.54 \\
7.53 \\
7.57\end{array}$ & $\begin{array}{l}2.91 \\
3.22 \\
2.84 \\
2.78 \\
2.60 \\
2.87 \\
2.78 \\
2.87 \\
2.97 \\
2.76\end{array}$ & $\begin{array}{l}20.1 \\
19.3 \\
19.8 \\
19.8 \\
19.8 \\
19.5 \\
19.6 \\
19.2 \\
19.5 \\
19.7\end{array}$ & $\begin{array}{l}34.4 \\
34.4 \\
34.4 \\
34.4 \\
34.6 \\
34.9 \\
34.6 \\
34.4 \\
34.9 \\
34.4\end{array}$ & $\begin{array}{l}28.1 \\
27.8 \\
28.9 \\
28.6 \\
28.8 \\
28.5 \\
28.6 \\
27.6 \\
29.2 \\
29.1\end{array}$ & $\begin{array}{l}11.1 \\
11.2 \\
10.9 \\
10.8 \\
10.3 \\
10.5 \\
10.9 \\
10.9 \\
11.0 \\
10.6\end{array}$ & $\begin{array}{l}52.9 \\
51.3 \\
53.4 \\
53.4 \\
54.4 \\
54.4 \\
52.5 \\
51.8 \\
54.1 \\
54.2\end{array}$ & $\begin{array}{r}7.0 \\
8.5 \\
9.0 \\
8.5 \\
9.0 \\
8.8 \\
8.5 \\
9.0 \\
10.0 \\
9.0\end{array}$ & $\begin{array}{l}0.0 \\
0.0 \\
1.5 \\
0.0 \\
0.0 \\
0.0 \\
0.0 \\
0.0 \\
0.0 \\
0.0\end{array}$ & $\begin{array}{l}442 \\
472 \\
442 \\
458 \\
362 \\
428 \\
461 \\
471 \\
510 \\
462\end{array}$ \\
\hline \multicolumn{13}{|l|}{ Site 320} \\
\hline $\begin{array}{l}1-2,144-150 \\
1-5,144-150 \\
3-2,144-150\end{array}$ & $\begin{array}{r}8.9 \\
13.4 \\
104.9\end{array}$ & $\begin{array}{l}7.37 \\
7.49 \\
7.29\end{array}$ & $\begin{array}{l}7.78 \\
7.79 \\
7.65\end{array}$ & $\begin{array}{l}3.65 \\
3.31 \\
3.85\end{array}$ & $\begin{array}{l}19.2 \\
19.3 \\
19.3\end{array}$ & $\begin{array}{l}34.6 \\
34.6 \\
35.2\end{array}$ & $\begin{array}{l}28.4 \\
- \\
27.1\end{array}$ & $\begin{array}{l}10.7 \\
10.6 \\
11.1\end{array}$ & $\begin{array}{l}52.6 \\
52.6 \\
54.0\end{array}$ & $\begin{array}{l}7.5 \\
8.5 \\
9.0\end{array}$ & $\begin{array}{l}3.5 \\
1.7 \\
0.0\end{array}$ & $\begin{array}{l}786 \\
820 \\
498\end{array}$ \\
\hline \multicolumn{13}{|l|}{ Hole 320B } \\
\hline $\begin{array}{l}1-5,143-150 \\
2-5,140-150\end{array}$ & $\begin{array}{l}143.4 \\
152.9\end{array}$ & $\begin{array}{l}- \\
-\end{array}$ & $\begin{array}{l}7.61 \\
7.66\end{array}$ & $\begin{array}{l}2.98 \\
2.61\end{array}$ & $\begin{array}{l}19.3 \\
19.4\end{array}$ & $\begin{array}{l}34.4 \\
34.1\end{array}$ & $\begin{array}{l}26.9 \\
27.6\end{array}$ & $\begin{array}{l}10.8 \\
10.7\end{array}$ & $\begin{array}{l}52.1 \\
52.0\end{array}$ & $\begin{array}{l}9.0 \\
6.0\end{array}$ & $\begin{array}{l}0.0 \\
0.0\end{array}$ & $\begin{array}{l}402 \\
358\end{array}$ \\
\hline \multicolumn{13}{|l|}{ Site 321} \\
\hline $\begin{array}{l}2-4,0-6 \\
4-3,144-150 \\
6-4,144-150 \\
9-6,0-6 \\
11-4,0-6 \\
13-3,0-6\end{array}$ & $\begin{array}{r}6.0 \\
24.4 \\
45.4 \\
75.5 \\
91.5 \\
118.5\end{array}$ & $\begin{array}{l}7.09 \\
7.43 \\
7.22 \\
7.20 \\
7.31 \\
-\end{array}$ & $\begin{array}{l}7.62 \\
8.23 \\
7.45 \\
7.44 \\
7.46 \\
7.50\end{array}$ & $\begin{array}{l}3.05 \\
3.34 \\
3.01 \\
3.24 \\
3.13 \\
2.86\end{array}$ & $\begin{array}{l}19.5 \\
18.6 \\
(16.6) \\
(17.0) \\
(17.9) \\
(18.4)\end{array}$ & $\begin{array}{l}34.9 \\
35.2 \\
35.2 \\
35.2 \\
35.2 \\
35.2\end{array}$ & $\begin{array}{l}28.2 \\
28.2 \\
28.5 \\
27.2 \\
27.2 \\
26.9\end{array}$ & $\begin{array}{r}10.5 \\
10.6 \\
10.9 \\
11.1 \\
10.8 \\
11.0\end{array}$ & $\begin{array}{l}53.4 \\
53.4 \\
54.6 \\
52.0 \\
53.6 \\
50.1\end{array}$ & $\begin{array}{l}7.5 \\
7.5 \\
5.5 \\
6.0 \\
7.5 \\
8.0\end{array}$ & $\begin{array}{l}3.5 \\
3.9 \\
7.4 \\
0.0 \\
1.0 \\
1.0\end{array}$ & $\begin{array}{l}765 \\
732 \\
670 \\
405 \\
357 \\
359\end{array}$ \\
\hline
\end{tabular}

Especially in Hole 319, the X-ray data reveal a relative increase in these zeolite contributions in the rapidly deposited middle Miocene section, i.e., below 30 meters. It is not likely that this material is redeposited and it has almost certainly been formed in situ. The zeolite phillipsite was proposed to form at the sediment-water interface by Bonatti (1963), supposedly as an alteration product of palagonite or, ultimately, from volcanic glass. Bernat et al. (1970) proposed the continued growth of phillipsite to a depth representing at least a million years. On the other hand, Czyscinski (1973) proposed the growth process to go to completion with a period of $1.5 \times 10^{5} \mathrm{yr}$. If the latter estimate were applicable to the sediments of Site 319 , then even at the high sedimentation rates of $2.8-4.2 \mathrm{~cm} / 1000 \mathrm{yr}$ in the lower 80 meters, the growth process could be completed at depths of less than 6 meters below the sediment-water interface. Even with the estimate of Bernat et al. (1970), the estimated depth of completion of this process would be at most 42 meters. Thus, the bulk of this zeolite and probably the associated clay mineral montmorillonite formed relatively shortly after deposition. This may explain the absence of any significant gradients in the major constituents of the interstitial water, if these constituents were important in the above alteration processes.

The presence of concentration gradients in Hole 245, (DSDP Leg 25) characterized by high Fe/Mn basal sediments, was interpreted in terms of on-going reactions at depth in the basal sediment layers. During the last $40 \times 10^{6} \mathrm{yr}$, sedimentation rates in Hole 245 have been $<0.5 \mathrm{~cm} / 1000 \mathrm{yr}$, and with the assumption of an apparent diffusion coefficient of dissolved calcium of 2 $\times 10^{-6} \mathrm{~cm}^{2} / \mathrm{sec}$ (Gieskes et al., in press), one can calculate a depth of $>300$ meters over which diffusional communication with the overlying seawater is possible (Lerman, 1971; Gieskes, 1975). We can say that any concentration gradients that originally were caused by different ionic concentrations in the interstitial waters of the basal sediments of Site 245 would be annihilated to $>95 \%$ over a depth of $>450$ meters. This, then leads to the conclusion that further reactions in the basal sediments of Hole 245 are the most likely explanation for the existence of concentration gradients, and not that they are remnants of a "fossil" concentration gradient that has not yet been smoothed out by diffusion. Applying a similar reasoning to Hole 319 , we find that, there, an average rate of sedimentation of $0.23 \mathrm{~cm} / 1000$ yr over the last 10 to 12 million years is applicable. This yields a communication depth (Gieskes, 1975) of $>300$ meters and a depth of about 220 meters over which $>90 \%$ of a "fossil" gradient should be wiped out by diffusional exchange with overlying seawater. Even with a diffusion coefficient of $8 \times 10^{-7} \mathrm{~cm}^{2} / \mathrm{sec}$ ( $\mathrm{Li}$ and Gregory, 1974), this conclusion would be valid. The absence of concentration gradients thus implies either the disappearance of any original concentration gradient or the fact that no significant reactions involving the major constituents of seawater occur after burial (at least not such reactions that would involve a change in the interstitial water composition). Similar analyses are applicable to Holes 320 and 321 . 
TABLE 2

Bulk Chemical Composition of Sediments Squeezed for Interstitial Waters

(All Data in Weight Percent)

\begin{tabular}{|c|c|c|c|c|c|c|c|c|c|}
\hline $\begin{array}{c}\text { Sample } \\
\text { (Interval in } \mathrm{cm} \text { ) }\end{array}$ & $\mathrm{Ca}^{\mathrm{a}}$ & $\mathrm{Mn}$ & $\mathrm{Fe}$ & $\mathrm{Al}$ & $\mathrm{Mg}$ & $\mathrm{Na}$ & $\mathrm{Sr}$ & $\mathrm{SiO}_{2}$ & $\mathrm{TiO}_{2}$ \\
\hline \multicolumn{10}{|l|}{ Site 319} \\
\hline $\begin{array}{l}1-3,0-10 \\
1-5,0-10 \\
2-3,0-10 \\
3-3,0-10 \\
5-6,0-10 \\
7-5,144-150 \\
9-2,140-150 \\
11-2,142-150 \\
11-5,142-150 \\
12-3,0-7\end{array}$ & $\begin{array}{l}2.14 \\
12.2 \\
29.5 \\
22.9 \\
43.1 \\
42.2 \\
37.9 \\
39.3 \\
35.5 \\
42.9\end{array}$ & $\begin{array}{l}3.47 \\
3.63 \\
1.21 \\
1.43 \\
0.144 \\
0.232 \\
2.62 \\
0.712 \\
0.736 \\
0.232\end{array}$ & $\begin{array}{c}13.9 \\
14.4 \\
4.7 \\
7.6 \\
0.5 \\
0.8 \\
1.45 \\
1.2 \\
1.7 \\
0.75\end{array}$ & $\begin{array}{l}2.41 \\
1.27 \\
0.29 \\
0.43 \\
0.03 \\
0.08 \\
0.14 \\
0.08 \\
0.11 \\
0.11\end{array}$ & $\begin{array}{l}2.27 \\
1.13 \\
1.13 \\
1.39 \\
0.18 \\
0.18 \\
0.27 \\
0.25 \\
0.44 \\
0.23\end{array}$ & $\begin{array}{l}4.80 \\
2.70 \\
1.41 \\
1.78 \\
0.48 \\
0.45 \\
0.56 \\
0.50 \\
0.62 \\
0.29\end{array}$ & $\begin{array}{l}0.043 \\
0.096 \\
0.119 \\
0.111 \\
0.125 \\
0.138 \\
0.126 \\
0.097 \\
0.112 \\
0.129\end{array}$ & $\begin{array}{l}30 \\
17.5 \\
12.0 \\
16.0 \\
0.57 \\
1.0 \\
1.7 \\
1.1 \\
1.5 \\
1.1\end{array}$ & $\begin{array}{l}0.60 \\
0.13 \\
0.040 \\
0.044 \\
0.0025 \\
0.0042 \\
0.016 \\
0.013 \\
0.013 \\
0.011\end{array}$ \\
\hline \multicolumn{10}{|l|}{ Site 320} \\
\hline $\begin{array}{l}1-2,144-150 \\
1-5,144-150 \\
3-2,144-150\end{array}$ & $\begin{array}{r}0.14 \\
1.50 \\
41.00\end{array}$ & $\begin{array}{l}0.074 \\
0.137 \\
0.581\end{array}$ & $\begin{array}{l}4.4 \\
4.0 \\
1.9\end{array}$ & $\begin{array}{l}8.15 \\
6.88 \\
0.09\end{array}$ & $\begin{array}{l}1.63 \\
1.59 \\
0.211\end{array}$ & $\begin{array}{l}2.60 \\
2.23 \\
0.37\end{array}$ & $\begin{array}{l}0.019 \\
0.018 \\
0.152\end{array}$ & $\begin{array}{c}53 \\
52 \\
2.2\end{array}$ & $\begin{array}{l}0.65 \\
0.53 \\
0.006\end{array}$ \\
\hline \multicolumn{10}{|l|}{ Site 320B } \\
\hline $\begin{array}{l}1-5,143-150 \\
2-5,140-150\end{array}$ & $\begin{array}{l}33.9 \\
37.2\end{array}$ & $\begin{array}{l}0.96 \\
0.697\end{array}$ & $\begin{array}{l}2.3 \\
1.1\end{array}$ & $\begin{array}{l}0.143 \\
0.101\end{array}$ & $\begin{array}{l}0.314 \\
0.287\end{array}$ & $\begin{array}{l}0.46 \\
0.41\end{array}$ & $\begin{array}{l}0.160 \\
0.142\end{array}$ & $\begin{array}{l}4.1 \\
3.1\end{array}$ & $\begin{array}{l}0.018 \\
0.015\end{array}$ \\
\hline \multicolumn{10}{|l|}{ Site 321} \\
\hline $\begin{array}{l}2-4,0-6 \\
4-3,144-150 \\
6-4,144-150 \\
9-6,0-6 \\
11-4,0-6 \\
13-3,0-6\end{array}$ & $\begin{array}{l}00.86 \\
0.75 \\
1.43 \\
24.3 \\
37.2 \\
32.2\end{array}$ & $\begin{array}{l}0.053 \\
0.071 \\
0.190 \\
1.86 \\
0.250 \\
2.79\end{array}$ & $\begin{array}{l}5.0 \\
5.2 \\
7.0 \\
9.6 \\
1.04 \\
5.3\end{array}$ & $\begin{array}{l}7.73 \\
7.52 \\
6.14 \\
1.48 \\
0.22 \\
0.26\end{array}$ & $\begin{array}{l}1.51 \\
1.69 \\
2.53 \\
0.603 \\
0.157 \\
0.314\end{array}$ & $\begin{array}{l}2.37 \\
2.40 \\
3.71 \\
0.76 \\
0.32 \\
0.50\end{array}$ & $\begin{array}{l}0.023 \\
0.022 \\
0.030 \\
0.118 \\
0.144 \\
0.118\end{array}$ & $\begin{array}{c}57 \\
- \\
45 \\
5.2 \\
2.0 \\
2.6\end{array}$ & $\begin{array}{l}0.88 \\
- \\
0.59 \\
0.11 \\
0.016 \\
0.037\end{array}$ \\
\hline
\end{tabular}

${ }^{\mathrm{a}}$ Data from Dr. Kurt Bostron; Ca values about $10 \%$ too high.

Even carbonate recrystallization reactions that often cause concentration gradients in dissolved strontium (Manheim and Sayles, 1974; Gieskes, 1974), especially in sediments with overall sedimentation rates of $>0.5$ $\mathrm{cm} / 1000 \mathrm{yr}$, do not leave an imprint in any of the sites drilled during this leg. Again, if such reactions do occur, they must be so slow in rate that any changes in dissolved strontium concentrations are annihilated by diffusional processes. We plan a more general discussion of diffusional processes elsewhere (Gieskes and Lawrence, in preparation).

Another way to distinguish any difference- between Site 245 and Sites 319, 320, and 321 is by means of a petrographic diagram suggested by Boström (1973) and by Boström et al. (this volume). In this, the ratio $\mathrm{Fe} / \mathrm{Ti}$ is plotted as a function of $100 \mathrm{Al} /(\mathrm{Al}+\mathrm{Fe}+\mathrm{Mn})$. On the basis of the composition of average continental crust material and that of average oceanic basalt, mixing lines can be generated, assuming mixing with an idealized ridge crest sediment. A similar diagram has been constructed using the data of Table 2 (Figure 1). In general, it appears that basaltic contributions to the sediments at Sites 319, 320, and 321 are much less important than those to the basal sediments of Site 245. The conclusions based on our Figure 1 are substantiated by the much more extensive set of data reported by Boström et al. (this volume). In the absence of such reactive material, no significant postdepositional reactions may occur in the sites drilled during Leg 34 except, perhaps, calcium carbonate recrystallization reactions.

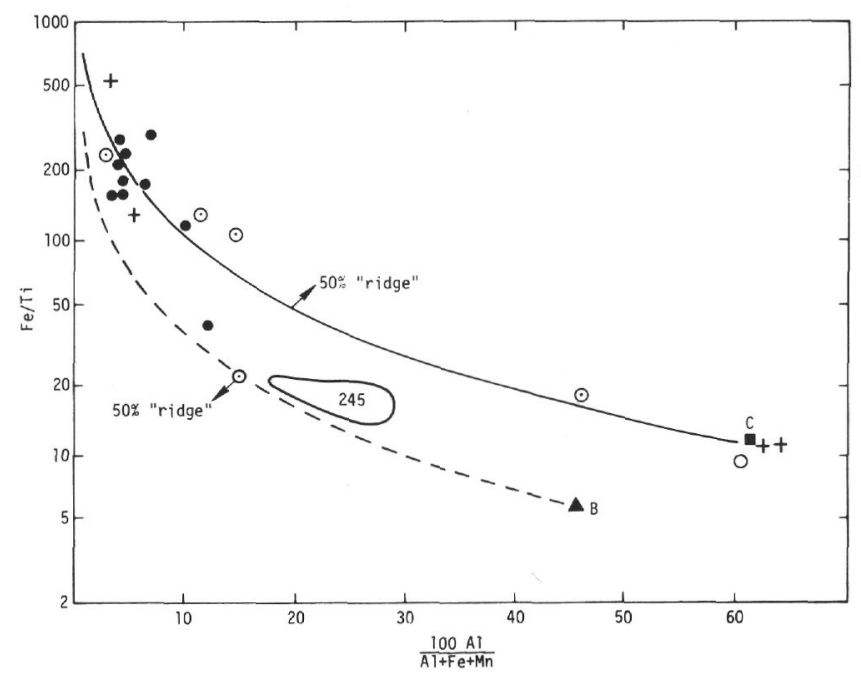

Figure 1. Relationships between $\mathrm{Fe} / \mathrm{Ti}$ and $\mathrm{Al}(\mathrm{Al}+\mathrm{Fe}+$ $M n)$ in Site 319, 320, and 321 sediments. $C=$ average continental crust; $B=$ average oceanic basalt. "Ridge" = material containing: $22 \% \mathrm{Fe}, 8.8 \% \mathrm{Mn}, 0.5 \% \mathrm{Al}$, and $0.02 \%$ Ti (Bostrom, 1973). $\bullet 319 ;+320 ; \cdot 321$.

\section{CONCLUSIONS}

Interstitial water studies on samples collected during Leg 34 reveal no significant changes in the major ionic constituents with respect to modern seawater. Only dissolved silica and manganese show relative enrichment, 
reflecting differences in mineralogical and redox conditions.

Our analysis of the problem of diffusional exchange leads to the suggestion that no major postdepositional reactions occur in these sediments that involve concentration changes of major constituents of interstitial dissolved salts. These conclusions are supported by an analysis of a petrochemical $\mathrm{Fe} / \mathrm{Ti}$ versus $\mathrm{Al} /(\mathrm{Al}+\mathrm{Mn}$ $+\mathrm{Fe}$ ) diagram.

Reactions causing the formation of zeolites and/or montmorillonites must have taken place shortly after deposition. A detailed chemical analysis of the noncarbonate phases may be relevant to determining the nature of these reactions.

\section{ACKNOWLEDGMENTS}

We appreciate the help of the shipboard chemist of the Glomar Challenger, Mr. Don Cameron. We thank Dr. Kurt Boström for making available his data on our sediments. This work was supported by NSF Grant GA-33229.

\section{REFERENCES}

Bernat, M., Bieri, R.H., Koide, M., Griffin, J.L., and Goldberg, E.D., 1970. Uranium, thorium, potassium, and argon in marine phillipsites: Geochim. Cosmochim. Acta, v. 34 , p. $1053-1071$.

Bischoff, J.L. and Sayles, F.L., 1972. Pore fluid and mineralogical studies of recent marine sediments: Bauer Depression region of East Pacific Rise: J. Sediment Petrol., v. 42 , p. 711-724.

Bonatti, E., 1963. Zeolites in Pacific pelagic sediments: N.Y. Acad. Sci. Trans., v. 25, p. 938-948.

Boström, K., 1973. The origin and fate of ferromanganoan active ridge sediments: Stockholm Contrib. Geol., v. 27, p. 149-243.
Czyscinski, K., 1973. Authigenic phillipsite formation rates in the central Indian Ocean and the Equatorial Pacific Ocean: Deep-Sea Res., v. 20, p. 555-559.

Dymond, J., Corliss, J.B., Heath, G.R., Field, C.W., Dasch, E.J., and Veeh, H.H., 1973. Origin of metalliferous sediments from the Pacific Ocean: Geol. Soc. Am. Bull., v. 84, p. 3355-3372.

Gieskes, J.M., 1974. Interstitial water studies, Leg 25. In Simpson, E.S.W., Schlich, R., et al., Initial Reports of the Deep Sea Drilling Project, Volume 25: Washington (U.S Government Printing Office), p. 361-394. 1975. Chemistry of interstitial waters of marine sediments: Earth Plan. Sci. Rev., v. , p. 433-453.

Gieskes, J.M., Kastner, M., and Warner, T.B.W., in press. Evidence for extensive diagenesis, Madagascar Basin, Deep Sea Drilling Site 245: Geochim. Cosmochim. Acta.

Lawrence, J.R., Gieskes, J.M., and Broecker, W.S., in press. Oxygen isotope and cation composition of DSDP pore waters and the alteration of Layer II basalts: Earth Planet. Sci. Lett.

Lerman, A., 1971. Time to chemical steady-state in lakes and ocean: Adv. Chem. Ser., v. 106, p. 30-76.

Li, Y-H. and Gregory, S., 1974. Diffusion of ions in seawater and in deep sea sediments: Geochim. Cosmochim. Acta, v. 38 , p. 703-714.

Manheim, F.T. and Sayles, F.L., 1974. Composition and origin of interstitial waters of marine sediments, based on Deep Sea Drill cores. In Goldberg, E.D. (Ed.), The sea, v. 5: New York (John Wiley \& Sons), p. 527-568.

Piper, D.Z., 1973. Origin of metalliferous sediments from East Pacific Rise: Earth Planet. Sci. Lett., v. 19, p. 75-82.

Sandstrom, M. and Gieskes, J.M., 1974. Interstitial water studies, Leg 24. In Fisher, R.L., Bunce, E.T., et al., Initial Reports of the Deep Sea Drilling Project, Volume 24: Washington (U.S. Government Printing Office), p. 799810.

Sayles, F.L. and Bischoff, J.L., 1973. Ferromanganoan sediments in the equatorial East Pacific: Earth Planet. Sci. Lett., v. 19, p. 330-336. 